\title{
FAKTOR-FAKTOR YANG MEMPENGARUHI PERILAKU PETANI DALAM MENERIMA PROGRAM KAWASAN RUMAH PANGAN LESTARI (KRPL) DI KABUPATEN PELALAWAN
}

\author{
Rahmi Puspita Sari ${ }^{1}$, Rosnita $^{2}$, Roza Yulida $^{3}$ \\ (1) Mahasiswa Pascasarjana Universitas Riau Pekanbaru \\ (2) \& (3) Dosen pada Program Studi Magister Agribisnis \\ Universitas Riau Pekanbaru \\ E-mail: rahmips@ymail.com
}

\begin{abstract}
The aims of this research are: (1) To determine the implementation of KRPL Programs, (2) To analyzing dominant indicator and influence of characteristic of innovation, communication channels, agent of change, community leaders and characteristic farmers. The research was conducted in 11 villages of Pelalawan Regency in 2013. The population is manager and members of farmers as 360 people which were taken 174 people as samples. The method used is descriptive analysis and Structural Equation Models (SEM). The research showed implemention of KRPL program in Pelalawan regency accepted Rp. 47.000.00 for each group. The coast was spent for environment industry like the source of food or cattle and fish.The most dominant indicator that influences characteristic of innovation is concord of program, for communication channel is social media, for agent of change is keep the program and prevent it from any sticking, for community leaders is to educator and the characteristic of farmer is subsistence level. Farmers habit in deciding the dominant is using confirmation step. The most influent variable of farmers habit is characteristic innovation.
\end{abstract}

Keywords : farmer, behavior, innovation adoption, KRPL programs.

Abstrak: Penelitian ini bertujuan untuk 1). Mengetahui pelaksanaan program KRPL, 2). Menganalisis indikator yang paling dominan dan pengaruh dari variabel Karakteristik Inovasi, Saluran Komunikasi, Agen Pembaru, Tokoh Masyarakat, Karakteristik Petani. Penelitian dilakukan di 11 Desa Tahun 2013 di Kabupaten Pelalawan. Populasi penelitian adalah pengurus dan anggota kelompok tani sebanyak 360 jiwa dan jumlah sampel sebanyak 174 jiwa. Metode analisis yang digunakan analisis deskriptif dan Structural Equation Models (SEM). Penelitian menunjukkan pelaksana program KRPL di Kabupaten Pelalawan menerima dana masing-masing kelompok sebesar Rp.47.000.000,- dan dikelola untuk usaha pekarangan seperti tanaman sumber pangan atau usaha ternak dan ikan. Indikator yang paling dominan mempengaruhi karakteristik inovasi adalah kesesuaian program, untuk saluran komunikasi yaitu media masa. Untuk Agen pembaru yaitu memelihara program dan mencegahnya dari kemacetan, dan tokoh masyarakat yakni peranan tokoh masyarakat sebagai penyuluh, serta karakteristik petani adalah tingkat subsistensi. Perilaku Petani dalam pengambilan keputusan dominan dibentuk oleh tahap konfirmasi. Variabel yang paling besar dalam mempengaruhi perilaku petani adalah Karateristik Inovasi

Kata Kunci : perilaku, petani, adopsi inovasi, program KRPL.

\section{PENDAHULUAN}

Indonesia dikenal sebagai Negara Agraris yang kaya dengan ketersediaan pangan dan rempah yang beraneka ragam. Berbagai jenis rempah dan obat-obatan dapat tumbuh di Indonesia. Indonesia saat ini tidak terlepas dari persoalan kritis pangan. Permintaan pangan yang semakin 
meningkat tidak diimbangi dengan penyediaan pangan mengakibatkan pangan Indonesia dari impor meningkat. Salah satu faktor dari permasalahan kritis pangan di Indonesia yaitu pertambahan penduduk. Peningkatan jumlah penduduk yang pesat dari tahun ketahun membuat pemenuhan kebutuhan pangan menjadi hal prioritas bagi setiap orang. Begitu juga dengan permasalahan lahan konversi yang meningkat dan pemenuhan pangan yang masih dibawah standart pemenuhan gizi. Untuk Hal itu pemerintah melakukan suatu langkah melalui upaya pemanfaatan lahan pekarangan dengan penggunaan sumberdaya lokal yang dikelola oleh rumah tangga yang disebut program Kawasan Rumah Pangan Lestari (KRPL). Program KRPL merupakan program dari Kementrian Pertanian yang dilaksanakan pada Tahun 2010 dan telah diterapkan diseluruh provinsi di Indonesia yang bertujuan untuk mengoptimalkan lahan untuk meningkatkan produksi tanaman pangan. Dalam menerima suatu adopsi inovasi peserta program banyak hal yang diduga mempengaruhi perilaku petani dalam menerima program. Proses perubahan perilaku petani tentu saja tidak serta merta terjadi begitu saja tetapi ada faktor dari internal dan eksternal yang mempengaruhi petani menerima program. Perilaku petani terhadap Program KRPL perlu diketahui karena keputusan untuk menerima dan menolak keberadaan program berasal dari petani selaku peserta. Faktor internal yang diduga mempengaruhi yaitu karakteristik penerima inovasi dan faktor eksternal adalah karakteristik inovasi dan sistem sosial dalam hal ini saluran komunikasi, agen pembaru, tokoh masyarakat. Tujuan dalam penelitian adalah 1) Mengetahui pelaksaan program KRPL. 2). Menganalisis indikator yang paling dominan dari a). Karakteristik Inovasi, b). Saluran Komunikasi, c). Agen Pembaru, d). Tokoh Masyarakat dan e). Karakteristik Petani. 3). Menganalisis pengaruh dari konstruk a). Karakteristik Inovasi, b). Saluran Komunikasi, c). Agen Pembaru, d). Tokoh Masyarakat, e). Karakteristik Petani terhadap perilaku petani dalam menerima program KRPL di Kabupaten Pelalawan.

\section{METODE PENELITIAN}

\section{Tempat dan Waktu Penelitian}

Penelitian dilakukan di Kabupaten Pelalawan Provinsi Riau. Penentuan lokasi penelitian dilakukan dengan sengaja (purposive). Penelitian dimulai pada Bulan Maret 2016 sampai Bulan Juni Tahun 2016. Objek penelitian adalah penerima program KRPL pada Tahun 2013.

\section{Populasi dan Teknik Pengambilan Sampel}

Populasi penelitian adalah anggota dan pengurus kelompok penerima program KRPL Tahun 2013 jumlah anggota sebanyak 360 petani yang tersebar di 11 Desa di Kabupaten Pelalawan. Penetapan jumlah sampel penelitian penulis mengacu kepada pendapat (Ghozali, 2008 dalam Haryono dan Wardoyo, 2013) yang mengatakan syarat jumlah sampel yang harus dipenuhi jika menggunakan analisis Structural Equation Model (SEM) yaitu minimal 5 kali jumlah indikator atau maksimal 10 kali jumlah indikator. Besarnya sampel sangat memengaruhi interprestasi SEM. Dengan demikian jumlah sampel penelitian ini adalah: Sampel minimal $=$ Jumlah indikator x $5=29$ indikator x $5=145$ sampel

Sampel maksimal $=$ Jumlah indikator $\mathrm{x} 10=29$ indikator x $10=290$ sampel

Antara rentang 145 hingga 290 sampel, peneliti memutuskan untuk mengambil 174 sampel yaitu (29 indikatorx6) $=174$ sampel .

\section{Teknik Pengumpulan Data}

Data yang dikumpulkan dalam penelitian ini terdiri dari data primer dan data sekunder. Data primer merupakan data yang dikumpulkan langsung dari sumber pertama yakni anggota dan pengurus Kelompok KRPL dengan wawancara. Data sekunder yang dikumpulkan berkaitan dengan monografi lokasi penelitian, data-data pendukung atau potensi aktual mengenai kondisi geografis ataupun data tentang kelompok tani di Kabupaten Pelalawan. Model dalam penelitian ini adalah Karakteristik Inovasi (X1), Saluran Komunikasi (X2) Agen Pembaru, Tokoh Masyarakat (X4), dan Karakteristik Petani (X5) (X3) dianggap sebagai variabel eksogen (variabel bebas) terhadap Perilaku Petani (Y) yang merupakan variabel endogen (variabel terikat). 


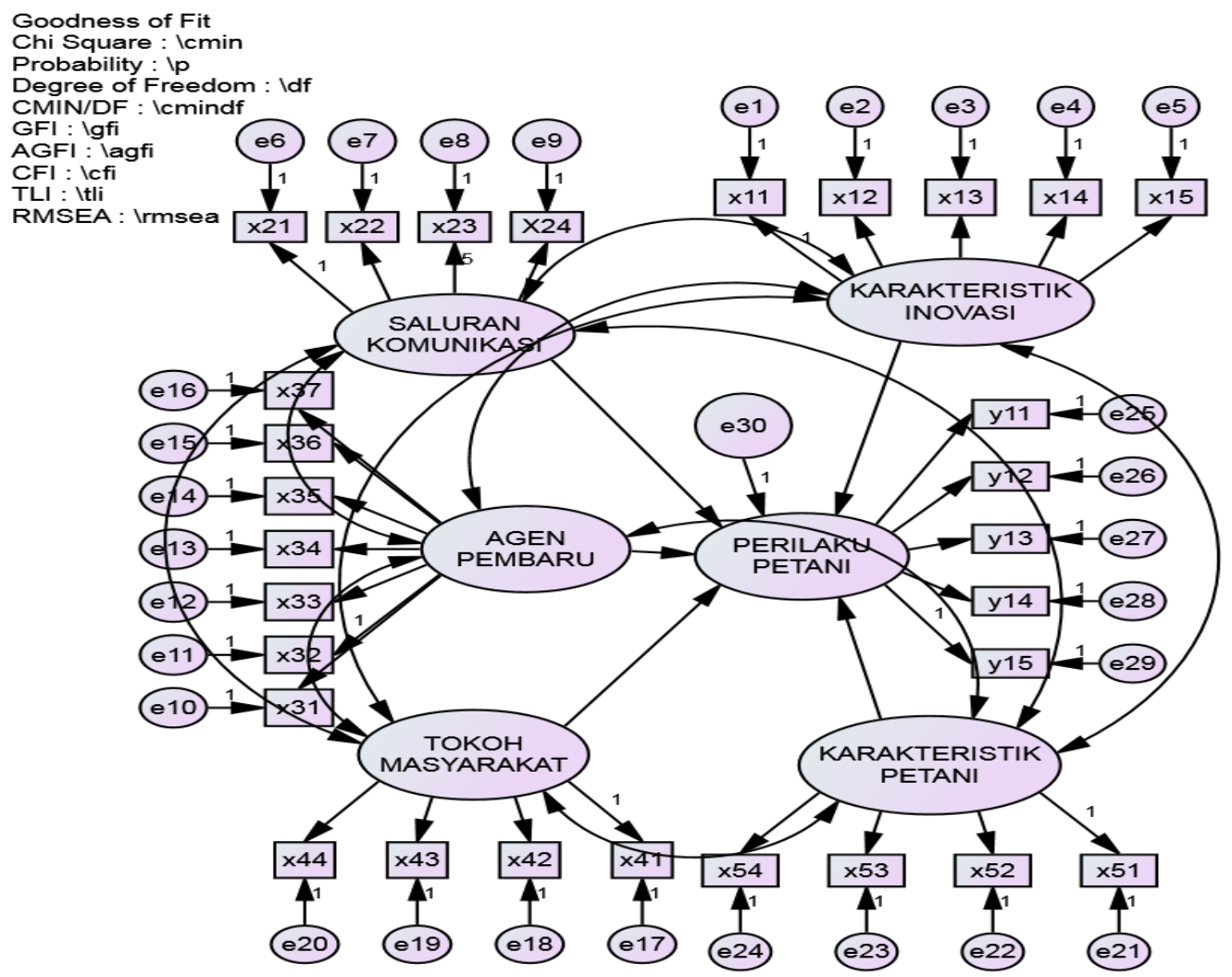

Gambar 1. Model SEM

\section{Metode Analisis Data}

Data dianalisis secara deskriptif dengan menggunakan Skala Likert's Summated Rating (SLR) dan metode Structural Equation Modelling (SEM). Model penelitian dikembangkan dan digambar pada path diagram. Sebelum dilakukan analisis pengaruh, ada beberapa uji asumi yang perlu dilakukan. Pengujian asumsi SEM yang perlu dilakukan adalah Uji Validitas dan Reabilitas Data, Outliers, Normalitas Data dan Multicollinearity dan Singularity (Latan, 2013). seluruh variabel yang berskala ordinal terlebih dahulu ditransformasikan tingkat kepengukurannya ke tingkat interval melalui Method of Succesive Interval (MSI) (Sarwono, 2010). Tahap pengujian asumsi SEM telah terpenuhi dan analisis dapat dilanjutkan.

Model SEM dapat dilihat pada Gambar 1 , dan variabel dan indikator yang selanjutnya dijabarkan di Lampiran 1.

\section{HASIL DAN PEMBAHASAN}

\section{Karakteristik Inovasi}

Karakteristik inovasi dilihat dari keuntungan relative, kesesuaian, kerumitan, dapat dicoba dan dapat diamati. Hasil penelitian menggambarkan bahwa program KRPL memberikan keuntungan terhadap peserta dibanding sebelum adanya program KRPL yang terlihat dari tersedianya pasokan makanan nabati dan hewani yang segar, pengeluaran rumah tangga menjadi berkurang, menambah pendapatan karena hasil tanaman pekarangan dapat dijual. Kesesuaian program dalam kondisi baik karena program yang dijalankan sesuai dengan kebutuhan petani dan sesuai dengan kondisi lahan, norma dan lingkungan, pengalaman usahatani petani, resiko program juga tidak besar serta tidak rumit untuk dijalankan karena bertani adalah mata pencaharian utama bagi petani. Tanaman pekarangan pun dapat dicoba dalam skala kecil dan diamati oleh petani. Hasil dari program pun cepat dirasakan oleh petani. Berdasarkan hasil analisis yang disajikan pada Gambar 2 . 


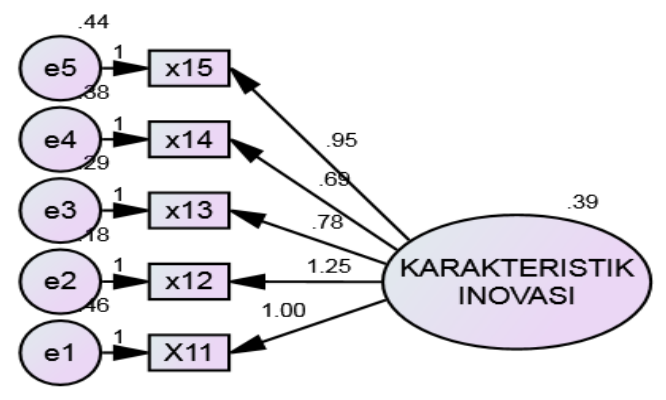

\author{
Goodness of Fit \\ Chi Square : 12.546 \\ Probability : .028 \\ Degree of Freedom : 5 \\ CMIN/DF : 2.509 \\ GFI : .973 \\ AGFI : .919 \\ CFI : .974 \\ TLI : .948 \\ RMSEA : .093 \\ RMR : .026 \\ NFI : .958
}

Gambar 2. Hasil CFA Karakteristik Inovasi
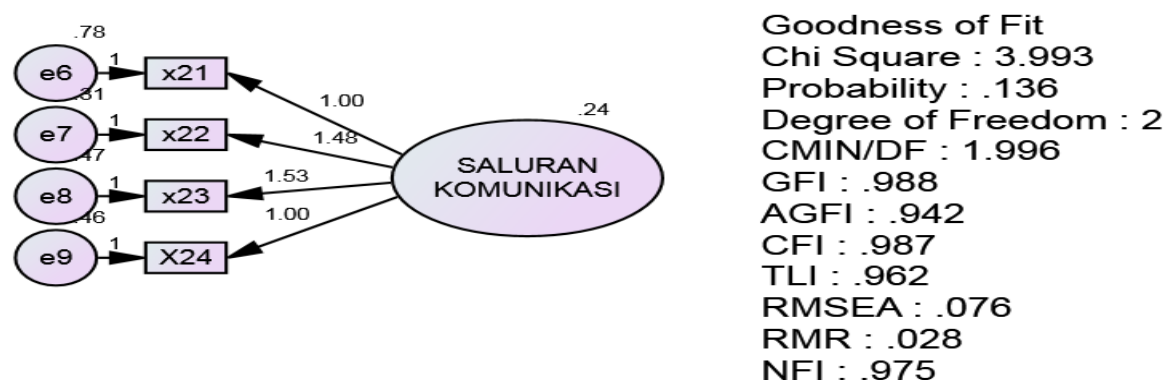

Gambar 3. Hasil Analisis Confirmantory Saluran Komunikasi

Indikator yang memiliki nilai estimate paling besar dalam mempengaruhi konstruk Karakteristik Inovasi adalah kesesuaian program terhadap kebutuhan peserta program (x1.2) sebesar 1,255, dalam hal ini program KRPL dianggap petani mampu membantu dalam memenuhi kebutuhan pangan rumahtangga petani. Nilai yang terendah adalah dapat dicoba (x1.4) sebesar 0,692. Secara berurutan indikator yang memiliki nilai paling besar adalah kesesuaian (x1.2) sebesar 1,255, keuntungan relative( $\mathrm{x} 1.1$ ) sebesar 1.000 , dapat diamati (x1.5) sebesar 0.956, kerumitan (x1.3) sebesar 0.782 dan dapat dicoba (x1.4) sebesar 0,692 . Indikator tersebut secara berurutan sesuai dengan kebutuhan masyarakat (peserta program) sehingga sangat penting untuk diperhatikan dan ditingkatkan tentang program yang akan lebih cepat diadopsi oleh masyarakat.

\section{Saluran Komunikasi}

Saluran komunikasi dilihat dari saluran komunikasi antarpribadi dan media masa serta saluran komunikasi yang bersifat local dan kosmopolit. Responden dalam penelitian lebih menyukai saluran komunikasi antarpribadi atau tatap muka sehingga petani dapat bertanya langsung kepada penyuluh tentang kendala program yang dihadapi dalam pelaksanaan ataupun yang lainnya. Saluran komunikasi media masa kurang efektif karena petani cenderung malas untuk membaca atau melihat informasi yang ada dan kesannya sulit dipahami. Untuk peserta program yang bersifat lokalit dan kosmopolit cenderung berkomunikasi dengan masyarakat (petani) lokal karena petani tidak memiliki relasi diluar desa dan sumber informasi yang didapatnya terbatas.

Indikator yang paling besar dalam mempengaruhi Saluran Komunikasi adalah saluran komunikasi yang bersifat lokal (x2.3) sebesar 1,534 dan yang terkecil adalah saluran komunikasi antarpribadi (x2.1) sebesar 1,000. Secara berurutan indikator yang memiliki nilai estimate paling besar adalah saluran komunikasi bersifat local (x2.3) sebesar 1,534, saluran komunikasi media masa (x2.2) sebesar 1.484, saluran komunikasi bersifat kosmopolit (x2.4) sebesar 1.003 dan saluran komunikasi antarpribadi (x2.1) sebesar 1,000. Indikator yang paling dominan yaitu saluran komunikasi yang berifat lokal agar lebih diperhatikan, karena saluran komunikasi yang bersifat lokal 

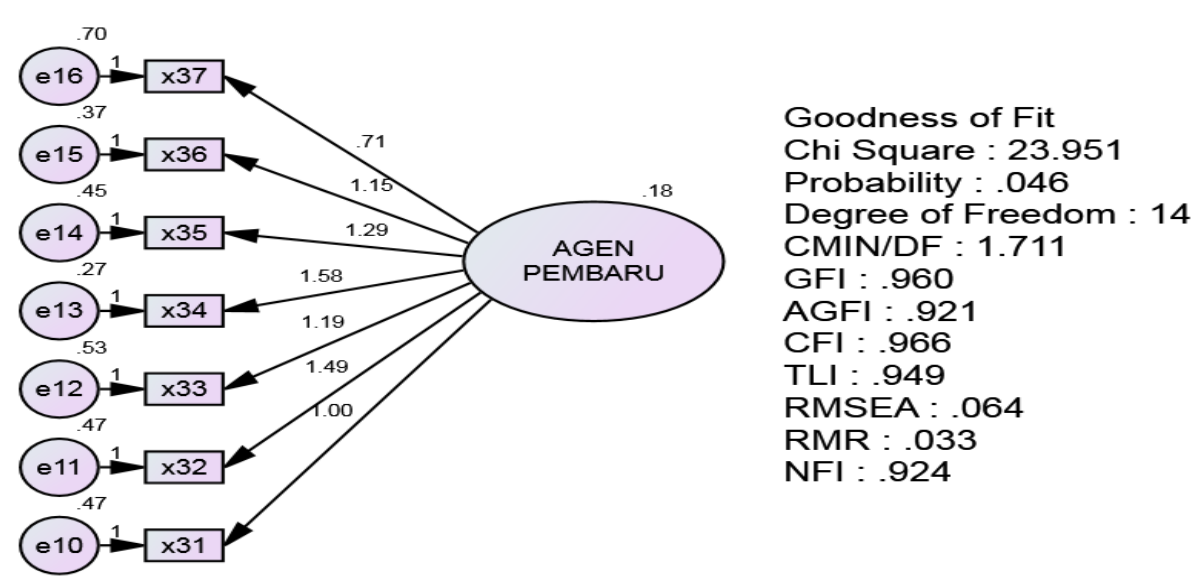

Gambar 4. Hasil Analisis Confirmantory Agen Pembaru

lebih cocok untuk komunikasi yang ada dipedesaan mengingat kebanyakan petani di desa cenderung tertutup dengan informasi dari luar.

\section{Agen Pembaru}

Agen pembaru (penyuluh) peranannya dalam menyampaikan adopsi inovasi kepada petani dengan saluran komunikasi yang baik sehingga petani dapat berubah perilakunya dalam menerima program KRPL. Agen pembaru telah dapat membangkitkan semangat petani untuk berubah dilihat dari kesenangan petani akan program dan motivasinya. Agen pembaru dekat dengan adopternya karena agen pembaru juga tinggal di Desa yang sama dan menggunakan bahasa yang sama dengan petani sehingga komunikasi tidak terhambat, akan tetapi agen pembaru masih belum dapat menyelesaikan masalah petani dilapangan. Solusi dari masalah yang dihadapi petani belum dengan serius diatasi. Agen pembaru juga tidak memiliki kemampuan dalam merencanakan tindakan pembaruan dan menciptakan kemandirian petani. Petani masih bergantung kepada penyuluh dalam berusaha tani sehingga jika tidak didampingi penyuluh petani cederung malas dalam berusahatani. Agen pembaru selalu memotivasi dan tidak bosan-bosan untuk mendorong minat petani dalam menanam dipekarangan. Penyuluh sering melakukan kunjungan.

Indikator yang paling besar dalam mempengaruhi Agen Pembaru adalah mendorong atau menciptakan motivasi untuk merubah pada diri peserta program (x3.4) sebesar 1,580, hal ini karena penyuluh tidak bosan-bosan untuk terus mengajak petani aktif dalam menanam dan membantu menyelesaikan masalah yang menghambat program tersebut. Nilai yang terendah adalah menciptakan kemandirian peserta program $(x 3.7)$ sebesar 0,711 , karena ketergantungan peserta program terhadap penyuluh masih tinggi. Secara berurutan indikator yang memiliki nilai estimate paling besar adalah mendorong atau menciptakan motivasi untuk merubah pada diri klien (x3.4) sebesar 1,580, mengadakan hubungan perubahan (x3.2) sebesar 1.494, merencanakan tindakan pembaruan (x3.5) sebesar 1.292, mendiagnosis masalah (x3.3) sebesar 1.194, memelihara program dan mencegahnya dari kemacetan (x3.6) sebesar 1.154, membangkitkan kebutuhan untuk berubah (x3.1) sebesar 1.000 dan Nilai yang terendah adalah menciptakan kemandirian adopter (x3.7) sebesar 0,711. Penyuluh masih belum mampu untuk menciptakan kemandirian pada diri petani untuk percaya kepada kemampuan yang dimiliki. Sehingga petani masih sangat bergantung kepada penyuluh mengenai usahataninya.

\section{Tokoh Masyarakat}

Tokoh masyarakat peranannya sebagai penyuluh penggerak, motivator dan teladan. Dalam suatu masyarakat biasanya ada orangorang tertentu yang dimintai nasehatnya oleh anggota masyarakat lain mengenai urusan tertentu. Tokoh masyarakat bisa menduduki jabatan formal ataupun nonformal dalam masyarakat.tokoh masyarakat adalah orang yang dekat dengan anggota masyarakatnya sehingga tingkah lakunya sering dicontoh dan saran yang diberikannya sering dipatuhi oleh masyarakat (Rogers, 2013). Hasil penelitian 


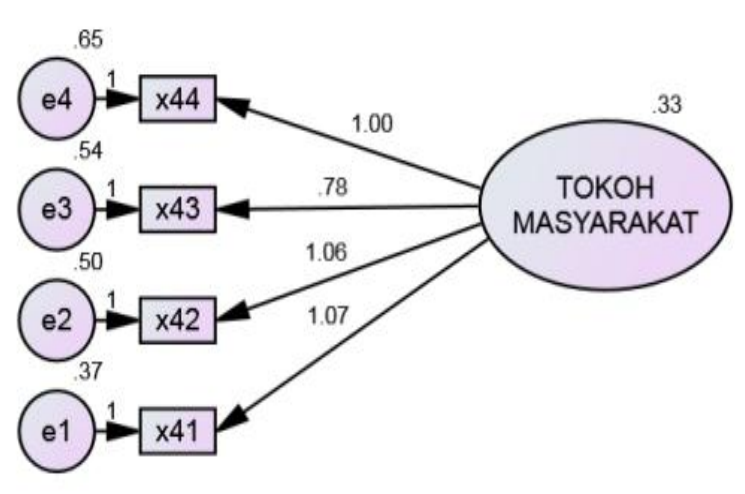

Goodness of Fit
Chi Square $: 2.531$
Probability $: .282$
Degree of Freedom : 2
CMIN/DF $: 1.265$
GFI $: .993$
AGFI : .963
CFI : .995
TLI : .986
RMSEA $: .039$
RMR : .020
NFI : .979

Gambar 5. Hasil Analisis Confirmantori Tokoh Masyarakat

menunjukkan bahwa peranan tokoh masyarakat dalam mempengaruhi petani di program KRPL dalam kategori cukup. Tokoh masyarakat tidak begitu mengenal dan peduli tentang progra KRPL. Hal ini terjadi karena tidak adanya hubungan komunikasi antara tokoh masyarakat dengan agen pembaru. Agen pembaru tidak mendekati diri kepada tokoh masyarakat. Untuk hal tersebut seharusnya agen pembaru bisa memanfaatkan peran tokoh masyarakat untuk membantunya. Menurut Rogers (1987) Agen pembaru dapat mengarahkan komunikasi dan memusatkan usahanya untuk mempengaruhi tokoh masyarakat dalam sosial itu, agen pembaru dapat menghemat tenaga, biaya dan waktu. Dengan menghubungi tokoh masyarakat berarti agen pembaru tidak perlu menghubungi adopter satupersatu karena setelah sampai ke tokoh masyarakat ide baru itu akan lebih cepat tersebar.

Indikator yang paling besar dalam mempengaruhi Tokoh Masyarakat adalah tokoh masyarakat sebagai penyuluh $\mathrm{x} 4.1$ ) sebesar 1,075, hal ini berarti tokoh masyarakat aktif terlibat dengan program. Sehingga tokoh masyarakat mampu mempengaruhi petani untuk menjalankan program KRPL dengan baik. Hasil yang terendah adalah tokoh masyarakat sebagai motivator $(\mathrm{x} 4.3)$ sebesar 0,778 . Tokoh masyarakat memang aktif terlibat dalam program KRPL akan tetapi perannya sebagai motivator tidak begitu baik. Hal ini terjadi karena tokoh masyarakat merasa tidak memiliki tanggung jawab untuk memotivasi petani. Tokoh masyarakat merasa penyuluh sudah cukup dalam memotivasi sehingga peranan ini tidak begitu diterapkan, akan tetapi dengan dibantu motivasi oleh tokoh masyarakat perilaku petani dalam menerima program juga akan meningkat. Secara berurutan indikator yang memiliki nilai estimate paling besar adalah tokoh masyarakat sebagai penyuluh $\mathrm{x} 4$.1) sebesar 1,075 , tokoh masyarakat sebagai penggerak (x2.4) sebesar 1.064, tokoh masyarakat sebagai teladan (x4.4) sebesar 1.000 dan tokoh masyarakat sebagai motivator (x4.3) sebesar 0,778.

\section{Karakteristik Petani}

Karakteristik petani dalam penelitian ini adalah keterampilan, motivasi berusaha, modal usahatani dan tingkat subsistensi. keterampilan dan motivasi berusahatani peserta program KRPL berada dalam kategori baik. Hal ini berarti petani telah terampil dalam menjalankan program KRPL karena memiliki pengalaman yang lama dalam usahatani, dan sebagian besar penerima program menjadi petani secara turun temurun. Program KRPL dalam pemanfaatan pekarangan bukan hal yang baru lagi bagi petani, begitu juga dengan alat-alat usahatani seperti cangkul, gembor, alat roundup, hand sprayer, serta pupuk seperti pupuk NPK, kandang, urea, KCL, pupuk dan pupuk SP36 yang dipakai telah bisa diusahakan dan dilakukan sendiri oleh petani. Motivasi berusahatani pun sangat besar karena bertani adalah sumber pendapatan petani sehingga petani sangat termotivasi untuk menjadi petani yang baik dan meningkatkan produksi usaha taninya dan menambah pendapatan untuk kebutuhan sehari-hari. Modal usahatani dan tingkat subsistensi berada dalam kategori cukup. Hal ini berarti bahwa petani terbatas 

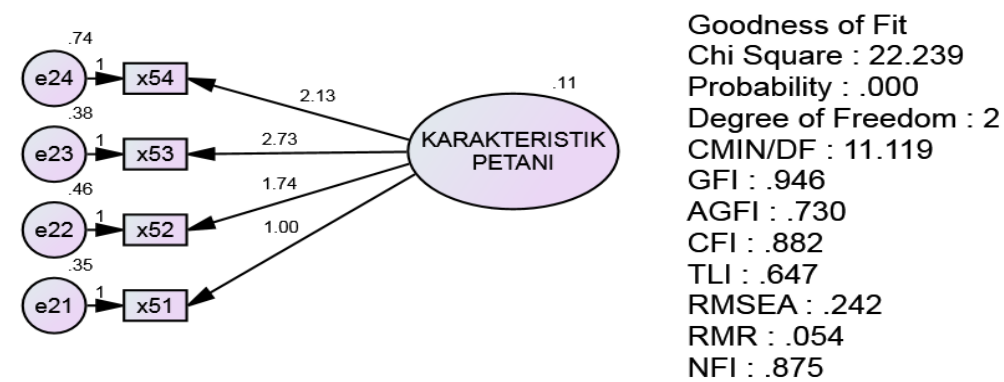

Gambar 6. Hasil Analisis Confirmantory Karakteristik Petani

kesempatan untuk mendapatkan modal dalam usahataninya. Sebagian dari petani hanya berharap bantuan program seperti dana dari program KRPL. Modal lanjutan petani mendapatkannya dari pinjaman keluarga atau tetangga karena untuk mendapatkan modal usaha tani dari lembaga perbankan akan membutuhkan jaminan dan prosedur yang harus dipatuhi, sementara petani tidak memiliki jaminan untuk meminjam. Hal ini juga terlihat dari tingkat subsistensi yang masih kurang, hal ini karena petani masih belum mendapatkan pendapatan yang cukup, apa yang telah diusahakannya masih sangat kurang dalam memenuhi kebutuhannya.

Indikator yang paling besar dalam mempengaruhi Karakteristik Petani adalah modal usaha tani (x5.3) sebesar 2,730 Modal usahatani yang berpengaruh besar dalam membangun Karakteristik Petani, harus lebih diperhatikan. Dengan tersedianya modal dan kesempatan untuk mengakses modal oleh petani maka akan meningkatkan perilaku petani. Keterampilan yang berada pada level yang paling rendah agar lebih ditingkatkan karena keterampilan dalam berusahatani akan berpengaruh terhadap hasil dari usahatani yang dijalankan. Hasil yang terendah adalah keterampilan (x5.1) sebesar 1,000. Secara berurutan indikator yang memiliki nilai estimate paling besar adalah modal usahatani (x5.3) sebesar 2,730, tingkat subsistensi (x5.4) sebesar 2.131, motivasi berusaha (x5.2) sebesar 1.741 dan yang terendah adalah keterampilan (x5.1) sebesar 1,000.

\section{Perilaku Petani}

Kulsum dan Jauhar (2014) mengartikan perilaku sebagai aktivitas yang ada pada individu sebagai akibat dari stimulus yang diterima, baik stimulus eksternal maupun internal. Berarti perilaku manusia sebagian berasal dari perilaku yang dibentuk, dan sebagian lagi berasal dari perilaku yang dipelajari. Dalam hal ini akan dilihat bagaimana perilaku petani dalam mengadopsi program KRPL dimulai dari bagaimana perilakunya dalam tahap pengetahuan, persuasi, pengambilan keputusan, implementasi dan konfirmasi.

Tahap pengetahuan dalam kategori baik, hal ini dimulai ketika petani mengetahui tentang program KRPL yang dilakukan saat sosialisasi. Petani mulai ingin tau tentang program, manfaat program dan kegiatan apa saja yang bisa dilakukan dalam program tersebut.

Tahap persuasi terlihat dalam kategori baik, petani senang dengan program KRPL dan yakin bahwa program KRPL dapat dijalankan dengan baik. Penyuluh sangat membantu petani pada tahap persuasi ini karena petani banyak bertanya tentang bagaimana kelanjutan program. Pendekatan penyuluh sangat baik kepada petani, penyuluh berusaha meyakinkan petani yang masih ragu untuk tetap melaksanakan program.

Tahap pengambilan keputusan dalam kategori baik yang berarti semua penerima program KRPL di Kabupaten Pelalawan menerima program dengan baik. Keyakinan petani dalam mengambil keputusan semakin kuat setelah dilakukannya sosialisasi dan juga praktek sekolah lapang yang dilakukan pada bulan Maret sampai Desember 2013.

Tahap implementasi berada pada kategori baik, hal ini berarti penerima program KRPL menerapkan program tersebut dan aktif dalam menjalankannya. Akan tetapi didalam perjalanan program terlihat terdapat beberapa kendala yang terjadi sehingga ada beberapa desa yang berhenti mengimplementasikan 


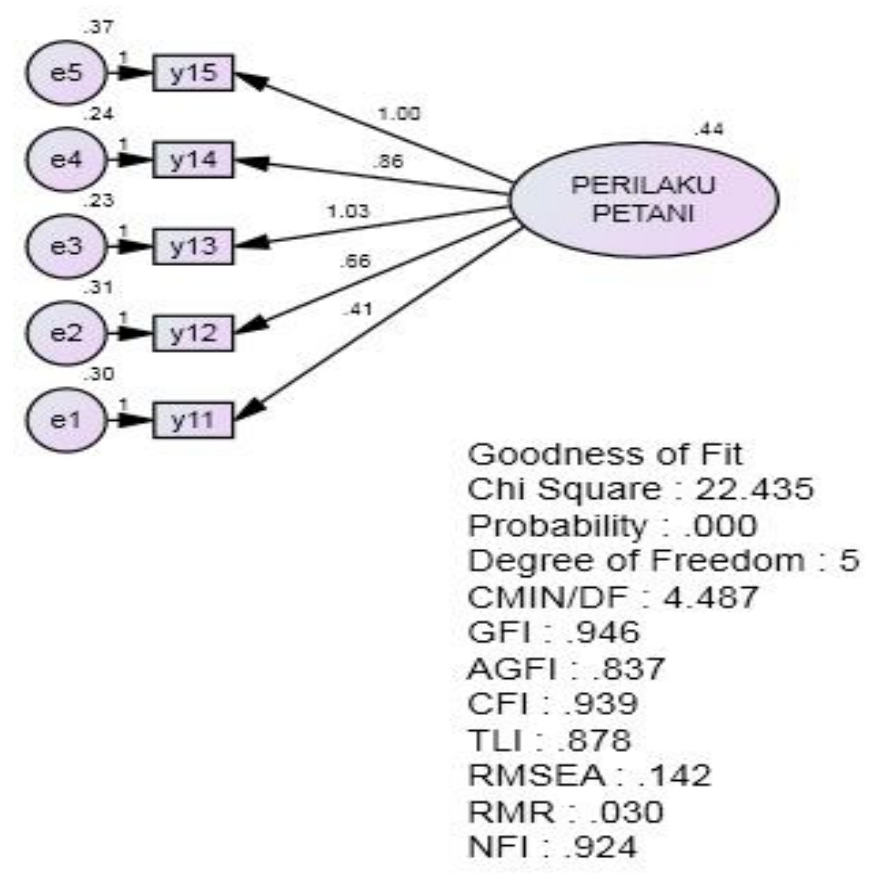

Gambar 7. Hasil Analisis Confirmantori Faktor

program, akan tetapi tidak menutup kemungkinan untuk petani dalam memulai program KRPL lagi, karena kendala yang terjadi bukan dari diri petani maupun dari inovasi progra $\mathrm{m}$ itu sendiri.

Tahap konfirmasi berada pada kategori baik hal, ini terlihat bahwa petani mencari informasi untuk menguatkan keputusan inovasi yang telah dibuatnya, tetapi mungkin petani akan merubah keputusannya jika memperoleh pesan-pesan yang bertentangan. Petani di Kabupaten Pelalawan tahun 2013 sampai saat ini masih menjalankan program KRPL. Hal ini karena petani senang akan program KRPL dan merasa mudah pelaksanaannya dan mengurangi kebutuhan belanja. Keuntungan-keuntungan seperti itulah yang membuat petani tetap menjalankan program KRPL ditambah dengan dukungan penyuluh yang aktif dimasingmasing desa untuk memberikan semangat dan motivasi serta mencarikan solusi yang ada didalam kelompok tani. Dengan adanya penyuluh petani merasa diperhatikan dan keputusannya dalam mengadopsi dirasa didukung oeh berbagai pihak.

\section{Perilaku Petani}

Standard loading yang membangun Perilaku Petani adalah 1.000, 0.856, 1.026, 0.663, 0,413. Indikator y1.1 (pengetahuan) memiliki nilai estimate dibawah 0,5, berarti y1.1 tidak diikutkan kedalam analisis selanjutnya. Indikator yang paling besar dalam mempengaruhi Perilaku Petani adalah tahap pengambilan keputusan (y1.3) sebesar 1,026 dan yang terkecil adalah tahap pengetahuan (y1.1) sebesar 0,413. Petani kurang mengetahui tentang program yang dijalankan akan tetapi sangat senang dengan kegiatan-kegiatan yang ada dalam program KRPL. Secara berurutan nilai estimate yang paling besar adalah tahap pengambilan keputusan (y1.3) sebesar 1,026, tahap konfirmasi (y1.5) sebesar 1.000, tahap implementasi (y1.4) sebesar 0.856, tahap persuasi (y1.2) sebesar 0.663 dan yang terendah adalah tahap pengetahuan (y1.1) sebesar 0,413

\section{Analisis CFA Variabel Eksogen}

Hubungan negatif terjadi antara variabel saluran komunikasi dan tokoh masyarakat yang dikenal dengan heywood case. Heywood case adalah istilah SEM ketika ditemukan adanya negative error variance (Latan, 2013). Haryono dan Wardoyo (2012) mengatakan, heywood case merupakan hal yang seharusnya sangat tidak mungkin terjadi karena nilai variance tidak mungkin negatif. 


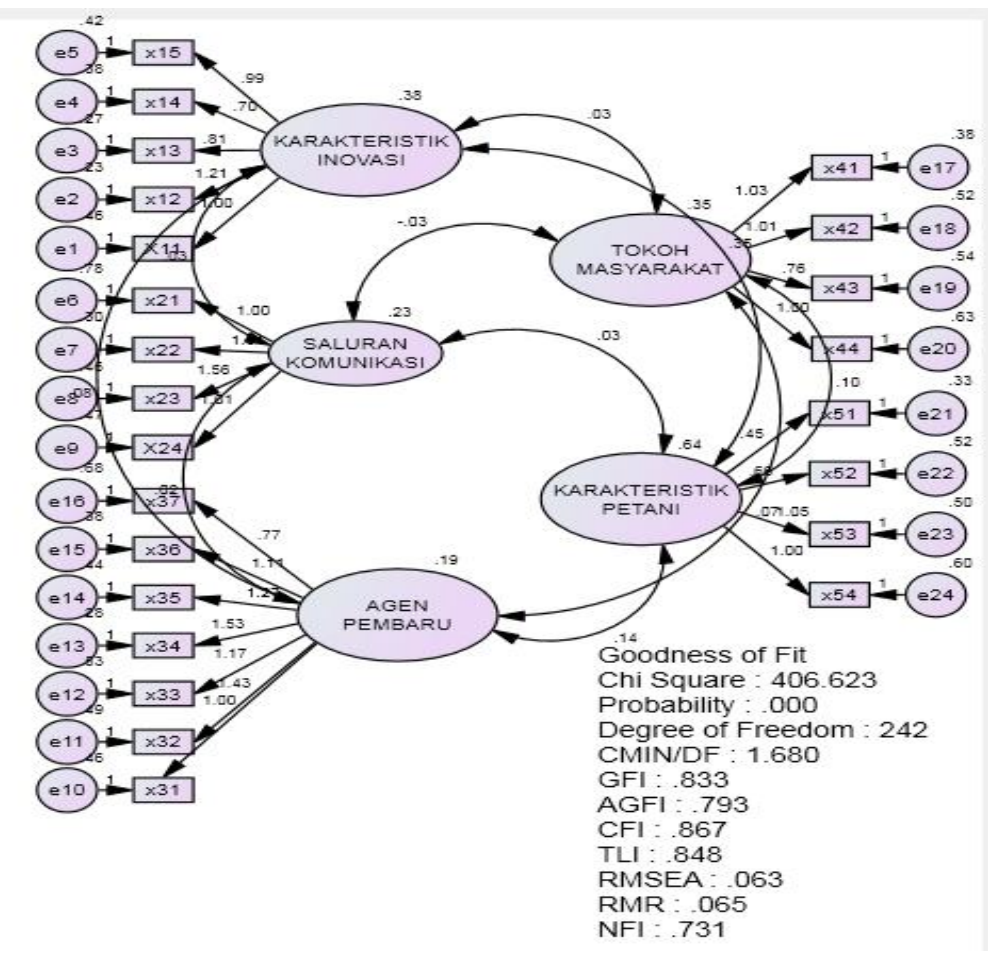

Gambar 8. Hasil Analisis Confirmantory Variabel Eksogen

Tabel 2. Ujian Kelayakan CFA Konstruk Eksogen

\begin{tabular}{|l|r|r|c|}
\hline $\begin{array}{l}\text { Goodness } \\
\text { of fit } \\
\text { indeks }\end{array}$ & $\begin{array}{c}\text { Cut-off } \\
\text { Value }\end{array}$ & $\begin{array}{c}\text { Hasil } \\
\text { Analisis }\end{array}$ & $\begin{array}{c}\text { Evaluasi } \\
\text { model }\end{array}$ \\
\hline Chi-square & 302.417 & 406,623 & Out Fit \\
Probability & $\geq 0.05$ & 0.000 & Out Fit \\
RMSEA & $\leq 0.08$ & 0.063 & Fit \\
GFI & $\geq 0.90$ & 0.833 & Marginal \\
AGFI & $\geq 0.90$ & 0.793 & Out Fit \\
CMIN/DF & $\leq 2.00$ & 1,680 & Fit \\
TLI & $\geq 0.90$ & 0.848 & Marginal \\
CFI & $\geq 0.90$ & 0.867 & Marginal \\
\hline
\end{tabular}

Bila hal ini terjadi maka model perlu diperbaiki dengan menetapkan error variance yang sebelumnya negatif menjadi positif dan kecil misal dengan mengganti nilai variance pada object properties menjadi 0.001 untuk c.r $>2,576$ atau 0.005 pada c.r >1,96 (Byrne, 1998 dalam Hayono dan Wardoyo, 2012). Hasil analisis Goodness of Fit yang dilakukan terhadap model CFA antar variabel eksogen yang dibangun masih belum memperlihatkan terpenuhinya uji kelayakan model yang dapat dilihat pada Tabel 2, berdasarkan evaluasi model yang telah dilakukan maka disimpulkan berada pada kondisi fit, marginal fit dan outfit.
Tabel 2 menjelaskan bahwa kategori fit ditemukan pada RMSEA dengan 0.063, dan CMIN/DF dengan 1.680. Kategori marginal ditemukan pada GFI dengan 0.833, TLI dengan 0.848 dan CFI dengan 0.867 sedangkan kondisi outfit ditemukan pada Chi square dengan 406.623, Probability dengan 0.000, dan AGFI dengan 0.793.

\section{Permodelan SEM Melibatkan Indikator Yang Dinyatakan Layak \\ Berdasarkan hasil analisis confirmatory factor} yang telah diuraikan pada bagian sebelumnya maka diperoleh gambar lengkap SEM dengan indikator yang dinyatakan layak pada gambar 8 berikut.

Hasil evaluasi terhadap model SEM yang dibangun, sebagaimana terlihat pada Gambar 8 masih memperlihatkan heywood case atau nilai estimate atau loading factor yang negatif, yakni antara saluran komunikasi dengan perilaku petani dalam mengambil keputusan sebesar 0,008. Berarti ketika saluran komunikasi meningkat sebesar satu satuan, maka perilaku petani akan berkurang sebesar 0,008 satuan. 


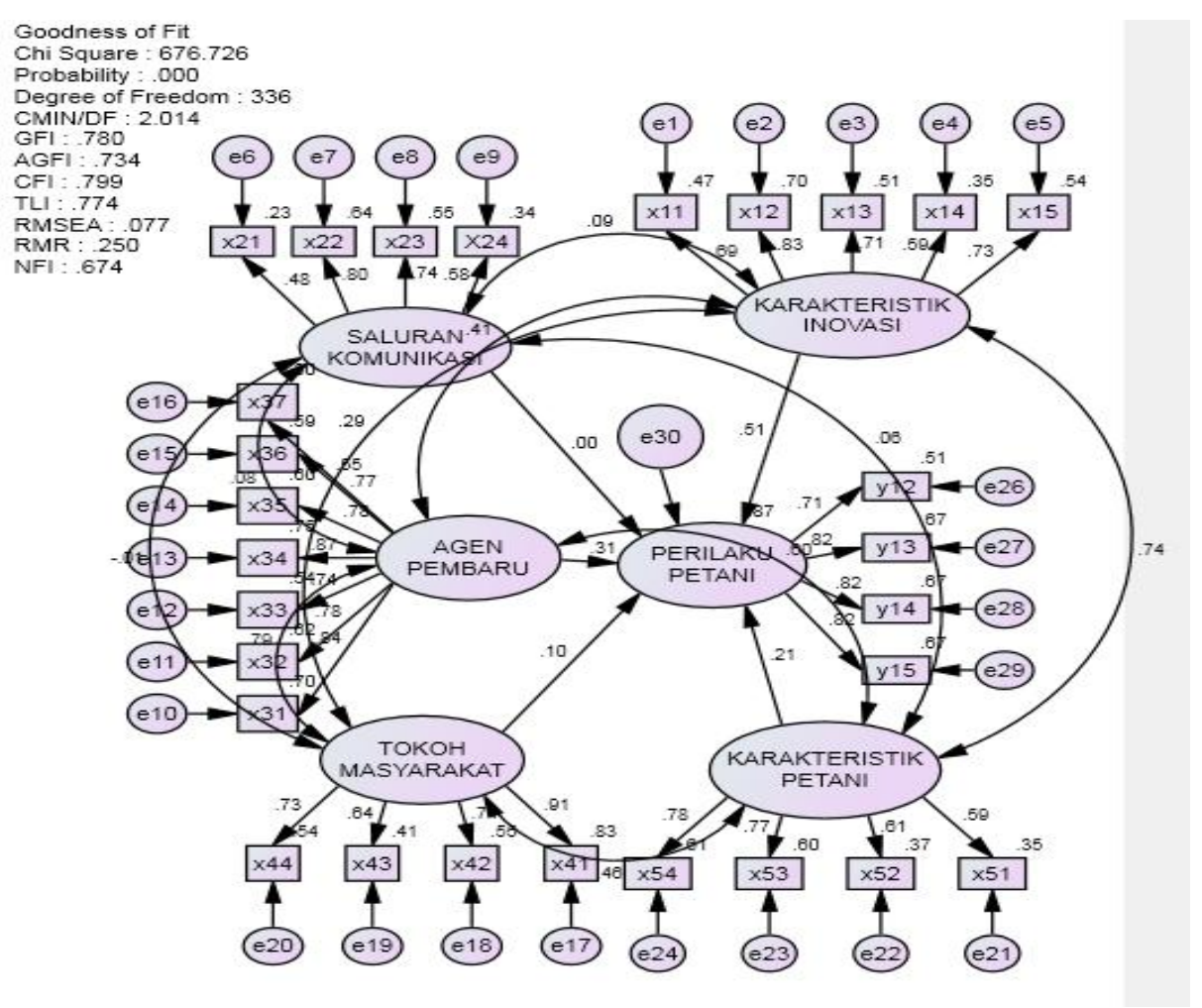

Gambar 9. Hasil Analisis Structural Equation Model

Hal ini karena semakin panjang saluran komunikasi semakin cenderung pula komunikasi itu berubah, dan komunikasi menjadi kurang baik dan lancar (Rakhmat, 1994).

\section{Permodelan SEM Modifikasi (Modification Indices)}

Heywood case tidak dibenarkan pada saat membangun permodelan SEM (Haryono dan Wardoyo, 2012). Menyikapi adanya hubungan atau nilai variance yang negatif pada model yang telah dibangun, peneliti lalu melakukan pengisian regression pada kotak object properties dengan angka 1 . Hasil penggantian nilai regression tersebut dapat dilihat pada Gambar 10. Gambar 10 memperlihatkan bahwa hubungan negatif yang terjadi antara saluran komunikasi dan perilaku petani dalam mengambil keputusan tidak lagi negatif, atau sudah menjadi 0,11. Haryono (2012) mengatakan model dapat dimodifikasi untuk menurunkan nilai chi square yang akan berdampak pada kriteria pengujian menjadi semakin fit. Salah satu caranya adalah berpatokan pada modification indices pada ouput analisa. Dengan modification indices maka peneliti dapat meminimalkan pembuangan indikator dalam satu variabel.

Hasil evaluasi terhadap model memperlihatkan bahwa Indikator yang paling dominan mempengaruhi karakteristik inovasi (X1) adalah X1.2 sebesar 0,839 satuan yaitu kesesuaian program. Program KRPL dinilai telah sesuai dengan kebutuhan petani, lingkungan, norma dan perilaku serta kebiasaan petani yang memang tidak asing lagi dengan pola menanam dipekarangan. Petani merasa ini sangat sesuai dan mudah diterima ditambah lagi dengan bantuan dana sehingga petani bisa memanfaatkannya dengan baik dan lebih beragam untuk konsumsi dan mandiri terhadap pangan keluarga dan mengurangi pembelian, serta menambah pendapatan dan meningkatkan gizi keluarga dengan makanan bergizi dan seimbang.

Indikator yang paling dominan mempengaruhi saluran komunikasi (X2) adalah X2.2 sebesar 0,792 satuan yaitu media masa. Agen pembaru dalam hal ini penyuluh telah mengembangkan cara berkomunikasi terhadap kliennya mengingat perkembangan zaman yang menuntut petani harus berpikir lebih luas lagi dan mampu mencari informasi yang lebih banyak. 


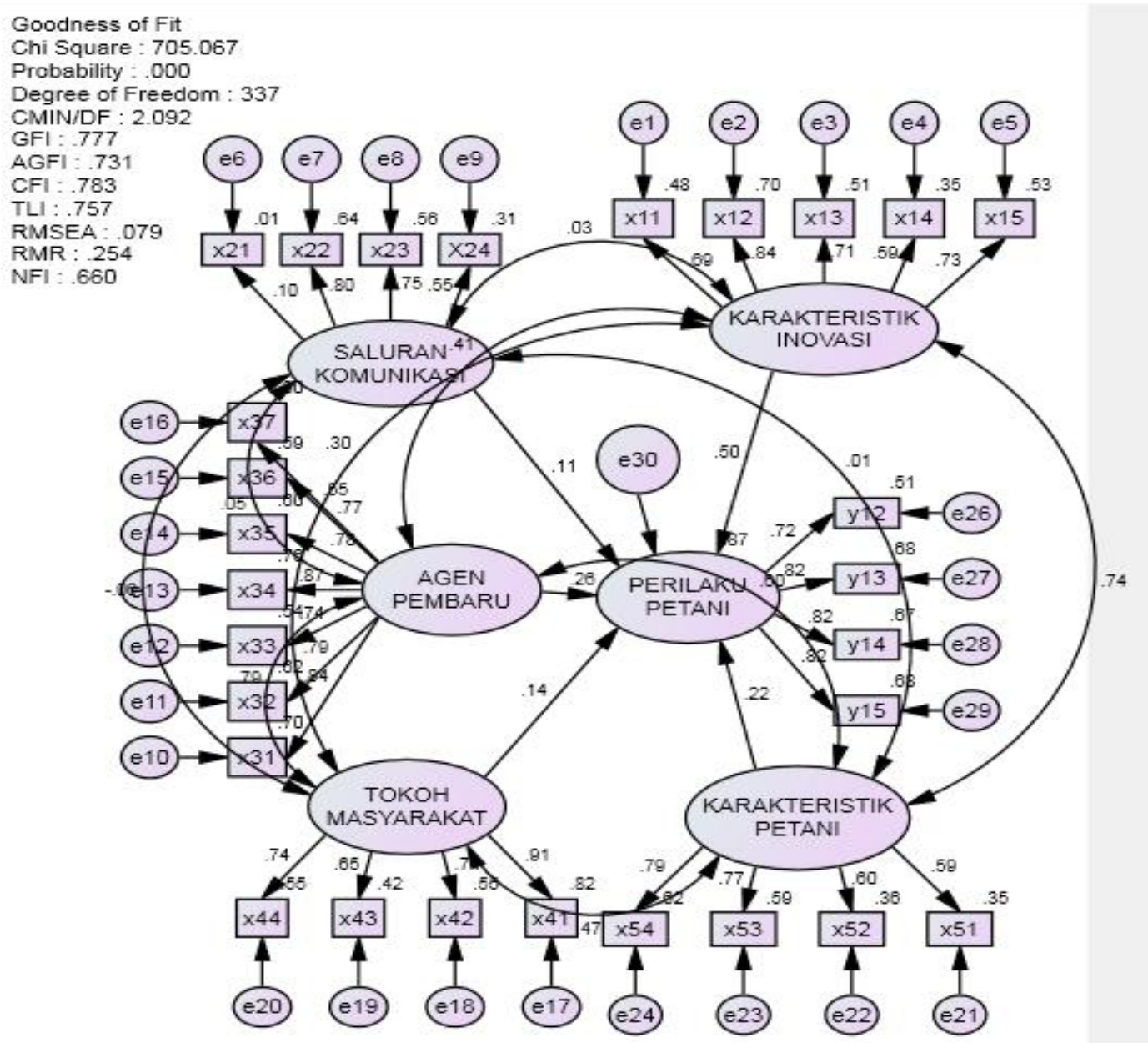

Gambar 10. Hasil Analisis Confirmantory Seluruh Variabel

Tabel 3. Hasil CFA setelah modifikasi

\begin{tabular}{|c|c|c|c|c|c|c|c|}
\hline & & & Estimate & S.E. & C.R. & $\mathrm{P}$ & Label \\
\hline $\begin{array}{l}\text { PERILAKU_PETA } \\
\text { NI }\end{array}$ & $<---$ & AGEN_PEMBARU & .223 & .093 & 1.661 & .097 & par_21 \\
\hline $\begin{array}{l}\text { PERILAKU_PETA } \\
\text { NI }\end{array}$ & $<---$ & TOKOH_MASYARAKAT & .462 & .170 & 1.758 & .079 & par_22 \\
\hline $\begin{array}{l}\text { PERILAKU_PETA } \\
\text { NI }\end{array}$ & $<---$ & KARAKTERISTIK_PETANI & .172 & .225 & 1.403 & .161 & par_23 \\
\hline $\begin{array}{l}\text { PERILAKU_PETA } \\
\text { NI }\end{array}$ & $<---$ & KARAKTERISTIK_INOVASI & .634 & .122 & 5.711 & $* * *$ & par_24 \\
\hline $\begin{array}{l}\text { PERILAKU_PETA } \\
\text { NI }\end{array}$ & $<---$ & SALURAN_KOMUNIKASI & .040 & & & & \\
\hline
\end{tabular}

Penggunaan media masa oleh penyuluh merupakan hal yang baru bagi petani sehingga dalam selingan tatap muka dengan penyuluh petani juga dapat membaca informasi, melihat, maupun mendengarkan hal yang kadang tidak petani dapatkan dari penyuluh.

Indikator yang paling dominan mempengaruhi agen pembaru (X3) adalah X3.6 sebesar 1,049 satuan yaitu memelihara program dan mencegahnya dari kemacetan. Agen pembaru dalam hal ini sangat ingin mempertahankan program dilihat dari adanya jadwal kunjungan rutin kepada kliennya dan agen pembaru juga memberikan kebebasan kepada klien untuk bertanya kapanpun jika terdapat masalah ataupun hal-hal yang tidak 
dimengerti petani. Agen pembaru ingin menanamkan dalam diri klien bahwa program yang berasal dari pemerintah tujuannya baik, membantu dan harus tetap dijalankan. Jangan sampai program yang digulirkan menjadi siasia dan tidak didapatkannya keuntungan dari klien tersebut.

Indikator yang paling dominan mempengaruhi tokoh masyarakat (X4) adalah X4.1 sebesar 0,914 yaitu tokoh masyarakat sebagai penyuluh. Tokoh masyarakat yang hidup ditengah masyarakatnya dinilai cukup peduli dan aktif serta membantu penyuluh dalam menjalani penyuluhan. Hal itu terbukti dengan tokoh masyarakat bahkan terlibat dan ikut mambantu dalam program KRPL karena tujuannya adalah untuk mensejahterakan petani dalam hal ini warga dari tokoh masyarakat ini sendiri.

Indikator yang paling dominan mempengaruhi karakteristik petani (X5) adalah X5.4 sebesar 0,846 yaitu tingkat subsistensi. Dari hasil program KRPL petani sudah merasa cukup dengan apa yang diperolehnya dalam program ini. Hasil dari tanaman dipekarangan sangat membantu petani dalam mengurangi pembeliaan bahan pokok.

Perilaku Petani (Y) dalam pengambilan keputusan dominan dibentuk oleh y1.5 yaitu sebesar 0,792 yaitu tahap konfirmasi. Perilaku petani dalam mengambil keputusan didasari oleh tahap-tahap yang telah dilewatinya dalam program KRPL. Tahap awal adalah tahap pengenalan dimana petani mengikuti sosialisasi program dan mengenal program yang akan diikutinya. Kemudian tahap persuasi dimana petani ingin mencari tau lebih banyak tentang program dan tahap pengambilan keputusan dimana petani memutuskan untuk mengadopsi program setelah melalui pertimbangan. Setelah memutuskan untuk mengadopsi program kemudian petani mulai mengimplementasikan program dan terlibat didalam program serta akan menerima hasil dari keputusannya untuk menerima program tersebut. Akan tetapi seiring berjalannya waktu dan melihat hasil yang didapat ada saja hal yang akan mempengaruhi keputusan petani tersebut dalam memandang program yang telah diadopsinya. Tahap konfirmasi adalah tahap dimana setelah hasil yang didapat petani memutuskan untuk tetap mengadopsi ataupun berhenti mengadopsi dalam hal ini bisa jadi karena petani menganggap hasil dari program tidak sesuai dengan dirinya ataupun kecewa dengan program.

Variabel yang paling besar dalam mempengaruhi perilaku petani secara berurutan adalah Karateristik Inovasi (X1) sebesar 0,634 satuan, Tokoh Masyarakat (X4) sebesar 0,462 satuan, Agen Pembaru (X3) sebesar 0,223 satuan, Karakteristik Petani (X5) sebesar 0,172 satuan dan Saluran Komunikasi (X2) sebesar 0,040 satuan. Apabila ditingkatkan masingmasing variabel tersebut maka juga akan meningkatkan perilaku petani. Variabel Karakteristik Inovasi menjadi faktor yang paling besar mempengaruhi perilaku petani , hal ini kemudian harus ditingkatkan dan diperhatikan. Sebab keuntungan relatif, kesesuaian dengan petani, mudah dilaksanakan, dapat dilihat dan diamati menjadi indikator yang sangat penting dalam merumuskan program baru untuk diadopsikan kepada masyarakat.

\section{KESIMPULAN DAN SARAN}

\section{Kesimpulan}

Berdasarkan analisis dan pembahasan yang telah dilakukan, maka dapat ditarik kesimpulan sebagai berikut:

1) Pelaksanaan program Pelaksaanaan KRPL pada Tahun 2013 di adopsi oleh 11 Desa di Kabupaten Pelalawan yang didampingi penyuluh. Besaran dana yang diterima masing-masing kelompok adalah Rp.47.000.000,- dan dikelola untuk usaha pekarangan seperti tanaman sumber pangan atau usaha ternak dan ikan.

2) Faktor yang paling dominan dalam membangun a). Karakteristik Inovasi (X1) adalah kesesuaian inovasi yang disampaikan terhadap penerima inovasi (X1.2) sebesar 0,839 satuan. b). Saluran komunikasi (X2) adalah saluran komunikasi media masa (X2.2) sebesar 0,792 satuan. c). Agen pembaru (X3) adalah peranan penyuluh dalam memelihara program pembaruan dan mencegahnya dari kemacetan (X3.6) sebesar 1,049 satuan. d). Tokoh masyarakat (X4) adalah peranan tokoh masyarakat sebagai teladan (X4.4) sebesar 0,914 satuan. e). Karakteristik petani (X5) adalah tingkat subsistensi (X5.4) sebesar 0,846 satuan. Itulah faktor yang mempengaruhi masing- 
masing konstruk dalam mempengaruhi perilaku petani dalam menerima program KRPL.

3) Faktor-faktor yang paling berpengaruh terhadap perilaku petani dalam menerima program KRPL secara berurutan adalah Karakteristik Inovasi (X1) sebesar 0,634 satuan, Tokoh Masyarakat (X4) 0,462 satuan, Agen Pembaru (X3) sebesar 0,223 satuan, Karakteristik Petani (X5) sebesar 0,172, Saluran Komunikasi (X2) sebesar 0,040 satuan. Artinya akan terjadi peningkatan pada perilaku petani dalam menerima program KRPL di Kabupaten Pelalawan apabila dilakukan peningkatan terhadap Karakteristik Inovasi (X1), Tokoh Masyarakat (X4), Agen Pembaru (X3), Karakteristik Petani (X5) dan Saluran Komunikasi (X2).

\section{Saran}

Pemerintah harus merumuskan secara baik dan matang tentang program yang akan diberikan kepada masyarakat. Program yang keluar dari pemerintah harus sesuai dengan kebutuhan masyarakat. Pemerintah harus membuat evaluasi terhadap program yang diluncurkan agar perkembangan dana yang telah diberikan dapat terlihat dan perubahan apa yang terjadi pada masyarakat sasaran. Kegiatan penyuluhan diharapkan dapat lebih ditingkatkan peranannya dengan menggunakan saluran komunikasi yang sesuai dengan kondisi masyarakat dan tahap-tahap pengadopsian dimulai dari tahap pengenalan, persuasi, pengambilan keputusan, implementasi dan konfirmasi. Peranan tokoh masyarakat juga harus lebih ditingkatkan. Agen pembaru harus mendekati tokoh masyarakat sebelum melakukan penyuluhan kepada kliennya agar tokoh masyarakat dapat bekerjasama. Hasil penelitian menjelaskan bahwa faktor yang paling mempengaruhi perilaku petani dalam mengambil keputusan adalah Kakteristik
Inovasi (X1) dengan pengaruh sebesar 0,634. Untuk itu perhatian pemerintah dalam membuat program sesuai dengan karakteristik inovasi harus lebih diperhatikan karena keuntungan relative, kesesuaian, kerumitan, dapat dicoba dan diamati sangat penting perannya dalam tingkat pengadopsian.

\section{DAFTAR PUSTAKA}

Ghozali. Iman., 2009, Model Persamaan Struktural, Konsep dan Aplikasi Dengan Program AMOS 16.0, Badan Penerbit Universitas Diponegoro, Semarang.

Haryono, Siswoyo dan Parwoto Wardoyo. 2012. Structural Equation Modeling untuk Penelitian Manajemen Menggunakan AMOS 18.00. Bekasi: PT Intermedia Personalia Utama.

Kulsum, Umi \& Mohammad Jauhar. 2014. Pengantar Psikologi Sosial. Jakarta: Prestasi Pustaka Rakhmat, Jalaludin, 1994, Psikologi Komunikasi, Bandung: Remaja Rosdakarya.

Latan, Hengky., 2013, Model Persamaan Struktural Teori dan Impelementasi AMOS 21.0, Alphabeta, Bandung, Indonesia

Rogers EM. dan Shoemekers F 1998, Memasyarakatkan ide-ide baru. Hanafie, A, peneremah. Usaha nasional. Terjemahan dari:Communication Of Innovations. Offset Printing. Surabaya.

Rogers, EM.2003. Diffusion Of Innovation, Fifth Edition. The Free Press. New York.

Sarwono J. 2010, Mengubah data ordinal ke data interval dengan metode sukses interval (MSI). http://tnp2k.go.id, Diakses pada tanggal 4 Januari 2016. 
Rahmi P. S., Rosnita, Roza Y. : Faktor-Faktor yang Mempengaruhi Perilaku ...

Lampiran 1. Variabel dan Indikator Penelitian

\begin{tabular}{|c|c|c|c|}
\hline No & Variabel & Indikator & Notasi \\
\hline 1. & $\begin{array}{l}\text { Karakteristik } \\
\text { Inovasi (X1) }\end{array}$ & $\begin{array}{l}>\text { Keuntungan Relatif } \\
>\text { Kesesuaian } \\
>\text { Kerumitan } \\
>\text { Dapat Dicoba } \\
>\text { Dapat Diamati }\end{array}$ & $\begin{array}{l}\mathrm{X} 1.1 \\
\mathrm{X} 1.2 \\
\mathrm{X} 1.3 \\
\mathrm{X} 1.4 \\
\mathrm{X} 1.5\end{array}$ \\
\hline 2. & $\begin{array}{l}\text { Saluran } \\
\text { Komunikasi (X2) }\end{array}$ & $\begin{array}{l}>\text { Antar Pribadi } \\
>\text { Media Massa } \\
>\text { Saluran Lokal } \\
>\text { Saluran Kosmopolit }\end{array}$ & $\begin{array}{l}\mathrm{X} 2.1 \\
\mathrm{X} 2.2 \\
\mathrm{X} 2.3 \\
\mathrm{X} 2.4\end{array}$ \\
\hline ]3. & $\begin{array}{l}\text { Agen Pembaru } \\
\text { (X3) }\end{array}$ & $\begin{array}{l}>\text { Membangkitkan Kebutuhan Untuk Berubah } \\
>\text { Mengadakan Hubungan Perubahan } \\
>\text { Mendiagnosis Masalah } \\
>\text { Mendorong / Menciptakan otivasi Untuk Merubah Diri Klien } \\
>\text { Merencanakan Tindakan Pembaruan } \\
>\text { Memelihara Program Pembaruan dan Mencegahnya dari } \\
\text { Kemacetan } \\
>\text { Menciptakan Kemandirian Adopter }\end{array}$ & $\begin{array}{l}\text { X3.1 } \\
\text { X3.2 } \\
\text { X3.3 } \\
\text { X3.4 } \\
\text { X3.5 } \\
\text { X3.6 } \\
\text { X3.7 }\end{array}$ \\
\hline 4. & $\begin{array}{l}\text { Tokoh } \\
\text { Masyarakat (X4) }\end{array}$ & $\begin{array}{l}>\text { Sebagai Penyuluh } \\
>\text { Sebagai Penggerak } \\
>\text { Sebagai Motivator } \\
>\text { Sebagai Teladan }\end{array}$ & $\begin{array}{l}\mathrm{X} 4.1 \\
\mathrm{X} 4.2 \\
\mathrm{X} 4.3 \\
\mathrm{X} 4.4\end{array}$ \\
\hline 5. & $\begin{array}{l}\text { Karakteristik } \\
\text { Petani (X5) }\end{array}$ & $\begin{array}{l}>\text { Keterampilan } \\
>\text { Motivasi Berusaha } \\
>\text { Modal usaha tani } \\
>\text { Tingkat Subsistensi }\end{array}$ & $\begin{array}{l}X 5.1 \\
X 5.2 \\
X 5.3 \\
X 5.4\end{array}$ \\
\hline 6. & $\begin{array}{l}\text { Perilaku Petani } \\
\text { (Y) }\end{array}$ & $\begin{array}{l}>\text { Tahap Pengenalan } \\
>\text { Tahap Persuasi } \\
>\text { Tahap Pengambilan Keputusan } \\
>\text { Tahap Implementasi } \\
>\text { Tahap Konfirmasi }\end{array}$ & $\begin{array}{l}\text { Y1.1 } \\
\text { Y1.2 } \\
\text { Y1.3 } \\
\text { Y1.4 } \\
\text { Y1.5 }\end{array}$ \\
\hline
\end{tabular}

